\title{
Sustainable Project-Based Learning: A More Practical Approach
}

\author{
M. Mukunda Vani ${ }^{1}$, Yasser Mirza Baig ${ }^{1}$, Caroline Wesley ${ }^{1}$, Syed Rashid Iqbal ${ }^{1}$ \\ ${ }^{1}$ Department of Chemical Engineering, Anurag Group of Institutions, Hyderabad, India \\ 1hodchem@cvsr.ac.in, yasserbaig8@gmail.com, carolinewesley0607@gmail.com, rashidsyed24@gmail.com
}

\begin{abstract}
Sustainable Project Based Learning (SPBL), an approach which sustains on the root depth learning of concepts and can help to improve the ability of the students, to develop cognitive and socio-emotional skills. These skills, are the need of the hour and are required, to be successful in academics and also in professional life. The present educational system emphasizes more on the theory, and less attention is given for practicals and SPBL.
\end{abstract}

In project-based learning (PBL), the teachers' guide the students, in applying the engineering design concepts, and the students work in a team, to find the solution for the problem. The innovative educational proposal, presented in this paper is a sustainable project-based learning approach, which allows the students to develop their technical competencies, through real problem-solving situations.

Students are made into teams to carry out mini-project, based on a real problem that requires intellectual understanding. Suggestions were taken through google forms. The suggestions described that the implementation of a project in the earlier stages of Engineering would be extremely beneficial. We have considered a thermodynamic problem as an example scenario for infusing sustainable project-based learning. The same approach can be followed by other subjects in other academic years.

The students of $3^{\text {rd }}$-year $2^{\text {nd }}$ semester were allocated a project and assessed based on report writing and presentation. The results were productive and thus enhanced the essence of learning new concepts through a practical approach and has benefitted a lot of students. In future times, it does hold a great position in imparting technical education and a learning environment to future engineers.

Keywords: Project-based learning, Cognitive, Socioemotional, Competencies, and Problem-solving.

\section{Introduction}

Sustainable Project-based learning may look like a modern idea, but it's built on a respected foundation. It is purely based upon the elements which are required to meet the needs of the present without compromising the future generation's education. Confucius and Aristotle were active proponents of the method of learning by doing. Socrates advocated learn through inquiry, questioning, and critical thinking and these strategies are relevant today forming a pillar of SPBL classrooms (De Los Rios et al., 2010)
Problem-based learning appeared more than half a century ago, which became a practical teaching strategy for the varied subjects that included engineering, medicine, economics, and others. By adopting this approach, students get the ability to solve problems, or doing simulations similar to real-life (Shinde et al., 2014). SPBL provides an immense learning environment that is ideally suited to future engineers and has far-reaching implications to learn in a team atmosphere. The process of presenting a course underlined the difficulties of interdisciplinary work as well as the opportunities and challenges inherent in involving students in authentic research with communities.

Mini-projects meant exclusively for engineering students, provide an impetus to work hard and also give an edge in recruitment to ensure a fine career. Despite employment practices, more and more students take up mini-projects, to improve their skill-set, in the third year before submitting the final-year project.

Students have felt that sometimes they do not see the relevance of what they are taught to real-life practice (Wang et al., 2016). Until they learn practically and apply the learning to design mini-projects, they cannot state that they use them properly. All mini-projects are an important part of academics, but only through their effective use, they can create a niche of their own.

Presently, students of engineering show an interest in making mini-projects because they realize the worth of receiving practical training. They are also of the opinion that internships, conceptual based labs, mini as well as major projects give practical knowledge. Presently, owing to the software explosion, projects in the final year did not get serious attention due to their allowance and because the students were previously employed by the time the final year began.

Sustainable Project-based learning is built on a comprehensive approach that engages students to investigate authentic problems. Students learn actively and also participate in practical activities, whereas the lecturers guide them to succeed in the project work (Shekar, 2007).

In the present system of engineering education, the projects start when a student reaches in $4^{\text {th }}$ year $2^{\text {nd }}$ semester and the third year they conclude their mini-project. Most of the core subjects are not covered by labs or practical sessions, 
leading to a lack of interest in the subjects. The present work focuses on practical sessions and also on projectbased learning in engineering education (Seidel et al., 2011).

A survey was also conducted in which people suggested their ideas on projects. Based on the suggestions and feedback of stakeholders, recommendations and practices were proposed. The projects need to be introduced from first year onwards and can be applied in many subjects of the curriculum. As an example, Chemical Engineering stream was chosen and the outcomes of the introduction of SPBL was explained. The attempt of introducing SPBL into Engineering was performed on $3^{\text {rd }}$-year $2^{\text {nd }}$-semester students of 2017-2021 batch as an experimental approach. This method of SPBL can be applied to other streams of engineering as well.

Additionally, the industrial requirements can also be satisfied by developing a keen interest in the projects (Duch et al., 2001).

\subsection{Difference between Sustainable Project-Based Learning and Project-Based Learning}

Sustainable project-based learning is the mode of learning where it will groom the student in a more proper and balanced way than a general conventional way of project-based learning. Project-based learning's evaluation and assessment are carried out during the coursework (Jollands et al., 2005). Whereas SPBL comes at the later end of the semester, it is more beneficial for the students as they would have finished their semester exams while PBL does not follow this way. The assessments of the project work in SPBL are also carried out in a much transparent way to let know the students what skills do they possess and what not.

Devoting too much time to PBL can cause issues where students take standardized tests, as they may not have the breadth of knowledge needed to achieve high scores. As it is evident in India the PBL has not really yielded good results yet. Thus a newer approach was made to make it sustainable in dispensing engineering education in India.

In this way, SPBL provides a cutting edge over PBL and it instructs the present education system to implement SPBL in core engineering courses and in a much more proportionate way to process the success of students.

\subsection{Need for SPBL in Chemical Engineering Core Subjects}

Chemical Engineering course contains some core subjects where the lack of concentration emerges in student or faculty due to the unavailability of labs or projects in that particular subject and also makes it difficult to grasp the better understanding of the subject. The same should be applied to the other engineering streams as they may also lack the same concentration in studies and unable to develop innovative thinking in their engineering. To become better engineers in this fast-growing world, one has to stand out from others and be innovative (Thomas, 2000). There are very fewer chances of students being recruited by the company unless they are different from others (Prince and Felder., 2006). In this paper, an attempt is made to stress over the subjects where the importance of projects must be given instead of making them rote learning. This new approach focuses on the introduction of project-based courses.

The student while working on these projects will be able to learn how to define the problem statement, design process, teamwork, communication, decision making, problem solution and professionalism. The projects should also be assessed critically. It should check for the understanding of the problem statement, the addition of the theoretical concepts for the process design, selection of the optimum solution from the various alternatives and communicate the same most effectively. SPBL has an objective to develop lifelong learning along with professional reasoning skills (Polanco et al., 2001).

\section{Methodology to obtain basic information regarding the implementation of $S P B L$}

Initially, a survey was conducted to gauge the impact of including SPBL in Engineering Studies. The survey targeted B.Tech graduates and the faculty. The google forms were created that gave information about their project experience. This authentic feedback helped us to understand the application of SPBL for students and proposed a process of including the same in the curriculum.

Various questions were asked in the survey like:

1. What was the project undertaken and in which subject?

2. When was the referred project taken?

3. Which year you would advise your juniors to start projects?

4. How did the project handled add experimental learning to your profile?

5. Why do you think projects are an intricate part of the syllabus?

6. What was your experience whilst doing the project?

7. Give the list of projects undertaken in specific, to Engineering subjects.

The survey was performed on 150 people of various streams where 100 were from chemical engineering and rest were from other streams. Some of the people who participated in this survey were graduates and few of them still pursuing the B.Tech course.

Based on the results of the survey conducted, the following methodology was proposed to implement the SPBL in specific to Chemical Engineering course. 
From the survey, it was understood that the introduction of project-based learning in the curriculum provided with three main advantages:-

1. It makes training possible in technical, individual and contextual competence.

2. It deals with real problems in the professional sphere.

3. Collaborative learning is made possible by integrating research and teaching.

Based on the survey, it was decided to implement SPBL for $3^{\text {rd }}$-year $2^{\text {nd }}$-semester chemical engineering students. The course chosen as an example is Chemical Engineering Thermodynamics. The students were divided into five groups with each group consisting of 8 students for a class of 40 students. Here an attempt was made to create a group of 8 students to teach them the value of teamwork. The number of groups and size was manageable for a single teacher without assistance. The teacher ensured self-paced learning for students. Moreover, with this number of groups, the teacher had no difficulty to intervene at a key point to promote discussions and resolve conflicts and to gather class for a brief period to discuss overall progress.

The groups were formed by mixing students of high and low GPA so that an environment of competition among groups have prevailed. Roughly two class hours per week were allocated for this SPBL activity. At the end of the activity, the groups presented their results in a 10-minute presentation.

\subsection{Implementation of SPBL in Chemical Engineering - A Detailed Approach}

Chemical engineering is unique to engineering and uses several principles of physics, chemistry, mathematics, economics and biology, for the efficient use, production, designing, transporting and transforming energy and materials. Chemical engineers have the tasks in several aspects of plant design, plant operation, assessments of safety and hazards, process design as well as analysis, modelling, chemical reaction engineering, control engineering, nuclear engineering, as well as biological engineering, specification dealing with construction, and finally the operating instructions.
The Chemical Engineering course is designed in such a way that it provides most of its learning through practicals and projects (Banerjee, 2015). It is based mainly on outcome-based learning which can be acquired by implementing SPBL in the course (Tatar and Oktay, 2011). After the evident success of the implementation of SPBL in $3^{\text {rd }}$ year $2^{\text {nd }}$ Semester, It was decided to apply to rest of the B.Tech Programme where the outline of the project will be explained to the students during the class work before semester break and then the project work could be carried out during their leisure time. Similarly, other branches of B.Tech can also implement the SPBL in their courses.

\subsection{Outcome-Based Education}

It's a student-centric approach. It's not what a teacher teaches, it's what a student learns (Bloom, 1956). The desired outcomes are to be determined first and the program curriculum, teaching and learning methodology and supporting facilities are to be designed to acquire the intended outcomes, namely Program Specific Learning Outcomes (PSLO).

The student should have the ability to:

1. Apply knowledge of advanced mathematics, physical sciences and engineering principles to practical problems in their respective professions.

2. Meet specified objectives within realistic constraints such as economic, environmental, ethical, health and safety, manufacturability and sustainability in the field of chemical engineering.

3. Design innovative processes and equipment suitable to the contemporary needs of the chemical industry and to promote the qualities of leadership and employability and be able to work in multidisciplinary teams supported by continuous Industry - Institution interaction.

Sustainable project-based learning provides a course to fractionate it in properly balanced proportions. The curriculum in an engineering institute must be designed in such a way that it must carry out industrial visits as well as practicals. The fractions or proportions of the course must be carried out in a balanced fashion. They are shown in

\begin{tabular}{|c|c|c|c|c|}
\hline \multirow[t]{2}{*}{ Course Contents } & \multirow[t]{2}{*}{ Course outcomes } & \multicolumn{3}{|c|}{ Program Specific Learning Outcomes } \\
\hline & & PSLO1 & PSLO2 & PSLO3 \\
\hline \multirow[t]{2}{*}{$\begin{array}{l}\text { 1. Basics of Chemical Engineering } \\
\text { Thermodynamics. }\end{array}$} & $\begin{array}{l}\text { 1. Apply the basic thermodynamic laws and estimate the heat and work } \\
\text { requirements of Industrial Processes. }\end{array}$ & $\mathrm{X}$ & & $\mathrm{X}$ \\
\hline & $\begin{array}{l}\text { 2. Determine the thermodynamic properties of mixtures of gases, liquids } \\
\text { and solids and determine the efficiency of flow processes. }\end{array}$ & $\mathrm{X}$ & $\mathrm{X}$ & \\
\hline $\begin{array}{l}\text { 2. Thermodynamic properties of different } \\
\text { types of fluids. }\end{array}$ & 3. Determine the equilibrium states of a wide range of systems. & $\mathrm{X}$ & $\mathrm{X}$ & \\
\hline 3. Heat Effects of Industrial processes. & $\begin{array}{l}\text { 4. Solve problems dealing with multi-phase chemical systems and reactive } \\
\text { systems. }\end{array}$ & $\mathrm{X}$ & & $\mathrm{X}$ \\
\hline $\begin{array}{l}\text { 4. Production of power from heat: } \\
\text { Refrigeration and liquefaction. }\end{array}$ & $\begin{array}{l}\text { 5. Illustrate the application of Chemical Engineering Thermodynamics in } \\
\text { the design of Chemical Process Plants. }\end{array}$ & $\mathrm{X}$ & $\mathrm{X}$ & $\mathrm{X}$ \\
\hline \multicolumn{5}{|l|}{$\begin{array}{l}\text { 5. Solution Thermodynamics: Theory } \\
\text { and applications. }\end{array}$} \\
\hline \multicolumn{5}{|l|}{$\begin{array}{l}\text { 6. Phase Equilibria (VLE, LLE, VLLE, } \\
\text { SLE) }\end{array}$} \\
\hline 7. Chemical Reaction Equilibria. & & & & \\
\hline
\end{tabular}


Fig.1.

Table 1. Mapping of course outcomes to PSLOs

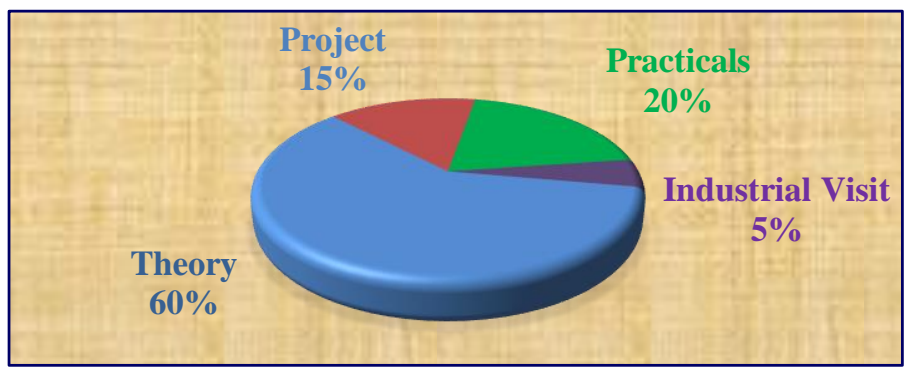

Fig.1 Fractions of a Course Content

SPBL can work very efficiently if this is applied from the starting of the B.Tech program in various Educational Institutes.

In the PSLO criteria, the course contents taught in chemical engineering thermodynamics (Smith et al., 2005), mapping of the course outcomes to PSLOs are provided in Table 1. To suffuse the project-based learning the course duration is divided between the perspective of student and teacher's learning. It can be decided to initiate the project after the completion of $60-70 \%$ of the course or in the vacations after they complete the semester as the condition most suited. We have introduced it in the latter part of the semester. About 2 teaching hours per week were allocated for teaching SPBL which covered 10-12\% of Program Outcomes.

\subsection{Designing Problem Statement}

The success of SPBL depends heavily on how the problem is designed and presented in an SPBL environment An exemplary problem should motivate students for deeper understanding. Moreover, it should be complex, real-world, multi-dimensional, open-ended and must revolve around the PSLO.

It must consist of a scenario which sets the context of the problem. This scenario in turn should consist of keywords that would guide students on how to start. Also, it should contain hooks which engage students in the context of the problem.

\subsection{Problem Statement}

The problem statement mentioned in this paper was used as an example to portray the impact of SPBL, The group of students may also be given the choice to design/define their own problem statement.

The problem posed to the students was to design the heating and cooling system for a typical house of a given size, based on a control volume analysis of the energy balance. The energy analysis was to be done for average and extreme summer conditions \& for average and extreme winter conditions for a specific location.
Climate data for the different states in India was made available to the students and each team selected a choice of state for them to work on. They were then asked to identify, evaluate and compare two choices for the heating and cooling systems:

(Choice 1) - Heat pump / Air conditioner system

(Choice 2) - Electric space Heaters and Central Air conditioner.

The problem was simplified in some parameters such as the infiltration of the house, the heat loss from the walls and roofs were given as inputs to the project (Narayanan, 2009). This was in line with the goals of the project which were to merely introduce the application of the topics of relevance to a thermodynamics course. Care was taken to ensure that the main characteristics of the calculations were kept as close to the practical case as possible so that the project was moderately open-ended.

Students have to present the findings to the class in $10 \mathrm{~min}$ presentation and submit a complete report elaborating their strategies to solve this problem and summarize their learning issues. They are assessed based on \% Specific learning outcomes (SLOs) achieved that covered during solving the problem.

Table 2. SLOs covered in the problem

\begin{tabular}{|c|l|}
\hline SLOs & \multicolumn{1}{|c|}{ Specific Learning Outcomes } \\
\hline SLO1 & Recalling and Examination of basic ideas. \\
\hline SLO2 & $\begin{array}{l}\text { Solve and Interpret information based on the provided } \\
\text { data. }\end{array}$ \\
\hline SLO3 & $\begin{array}{l}\text { Evaluating by inspecting \& prioritizing the problem } \\
\text { solution. }\end{array}$ \\
\hline SLO4 & Create, Design and Formulate a model. \\
\hline
\end{tabular}

\subsection{Results of the Assigned Project}

The students had performed fairly well in the report writing as well as in the presentation. The project has caused them to self-pace the concepts which are supposed to be understood in depth.

The analysis of the written report is shown in Fig. 2.

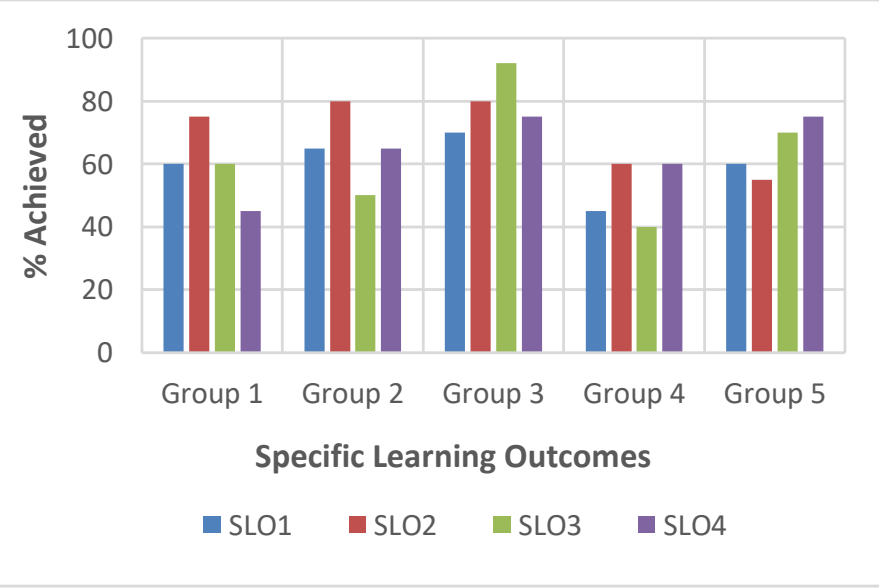




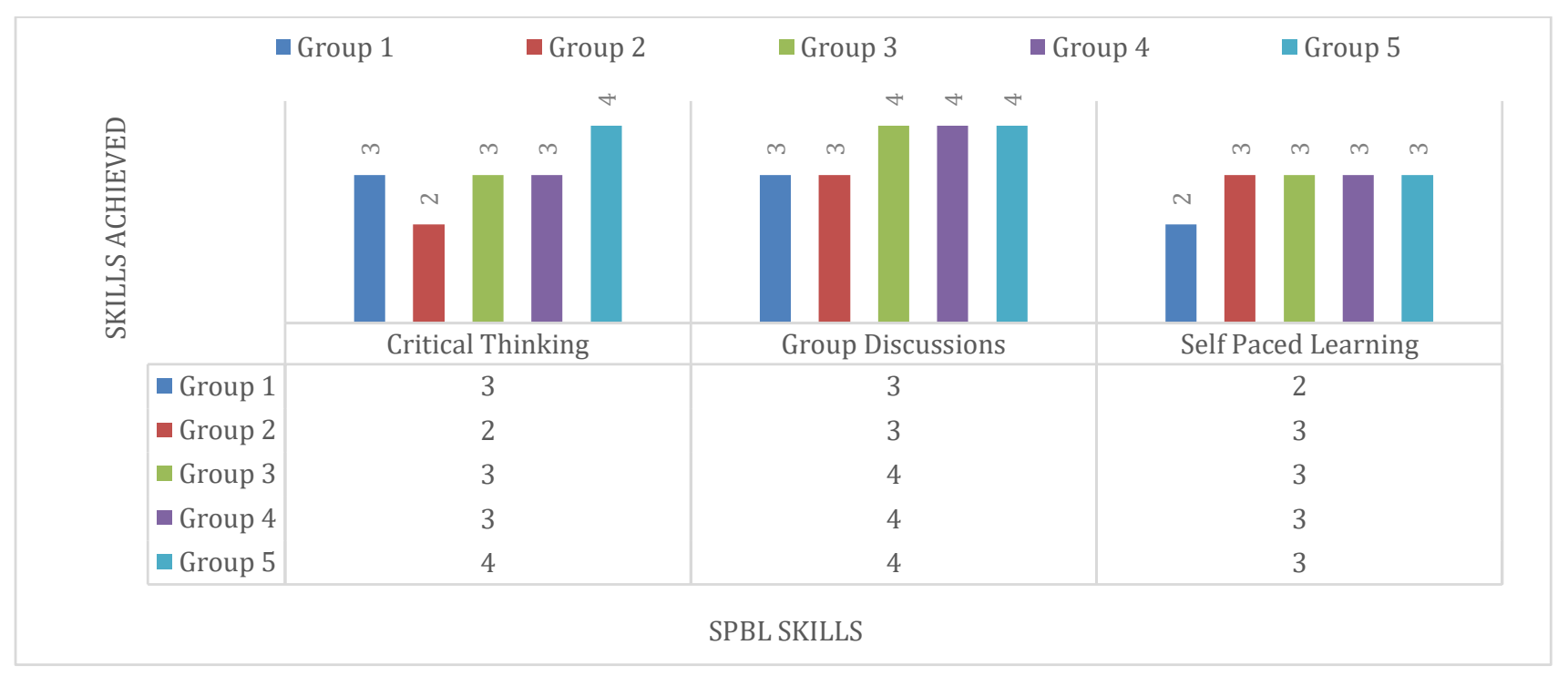

Fig.3 Analysis of SPBL Skills

In the analysis shown in Fig.3 ' 1 ' was given the rating of very poor, '2' as poor, ' 3 ' as good, '4' as very good and ' 5 ' as excellent. As it can be seen the ratings of critical thinking and group discussions are fair enough while the ratings of self-paced are a bit tender. The apparent ability of students stresses a call for SPBL implementation. The structure and assessment for presentation are based on the rubrics cube given in Table 3 . The marks are predefined on a set of points available for each criterion and are calculated according to it. Students worked in medium groups to pinpoint what they need to learn to solve a problem. They engaged in self-directed learning and then applied their new knowledge to the problem and reflected on what they learned and the effectiveness of the strategies employed. In other words, SPBL gave four dimensions to the process of learning such as constructive, self-directed, collaborative and contextual. Based on the written report, presentation and in-class discussions, the assessments were taken and concluded. The students were given marks according to their overall team performance. The individual strength of a student can be determined by the part he devotes to the teamwork. The rubrics mentioned are the required base to calculate the presentation part of the project.

\subsection{Potential Subjects for Sustainable Project Based Learning.}

The subjects mentioned in Table 4 may be suggested for the implementation of Sustainable project-based learning in Chemical Engineering education (Krishnan and Nalim, 2009).

\section{Table 3. The assessment basis for SPBL Skills}

\begin{tabular}{|c|c|c|c|c|}
\hline Element & $\begin{array}{c}\text { Needs Improvement } \\
1\end{array}$ & $\begin{array}{c}\text { Fair } \\
2\end{array}$ & $\begin{array}{l}\text { Strong } \\
\mathbf{3}\end{array}$ & $\begin{array}{c}\text { Excellent } \\
4\end{array}$ \\
\hline Topic & Topic is Unclear & $\begin{array}{l}\text { Introduces the topic but the focus } \\
\text { is unclear. }\end{array}$ & Introduces the topic. & Clearly introduces the topic. \\
\hline Evidence & $\begin{array}{l}\text { Little facts or examples } \\
\text { included }\end{array}$ & $\begin{array}{l}\text { Attempts to develop the topic } \\
\text { with facts, concrete details but } \\
\text { some information is not relevant. }\end{array}$ & $\begin{array}{l}\text { Develops the topic with facts, } \\
\text { concrete details and examples. }\end{array}$ & $\begin{array}{l}\text { Thoroughly develops the topic with } \\
\text { relevant facts, concrete details and } \\
\text { examples. }\end{array}$ \\
\hline $\begin{array}{l}\text { Explanation } \\
\text { and Analysis }\end{array}$ & $\begin{array}{l}\text { Little to no explanation and } \\
\text { analysis of information } \\
\text { presented. }\end{array}$ & $\begin{array}{l}\text { Attempt to discuss the } \\
\text { information but is unclear or lacks } \\
\text { depth. }\end{array}$ & $\begin{array}{l}\text { Clear explanation and analysis } \\
\text { that discusses most of the } \\
\text { information. }\end{array}$ & $\begin{array}{l}\text { Clear and concise explanation and } \\
\text { analysis that thoroughly discusses } \\
\text { the information presented. }\end{array}$ \\
\hline Conclusion & $\begin{array}{l}\text { Abrupt ending, No concluding } \\
\text { statement. }\end{array}$ & $\begin{array}{l}\text { Ends with a concluding statement } \\
\text { that doesn't clearly relate to the }\end{array}$ & $\begin{array}{l}\text { Ends with a concluding statement } \\
\text { about the topic. }\end{array}$ & $\begin{array}{l}\text { Effectively ends with a strong } \\
\text { concluding statement. }\end{array}$ \\
\hline
\end{tabular}




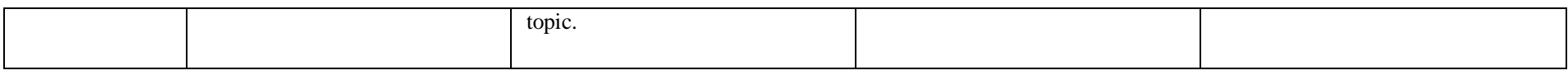

Table 4. Potential subjects for SPBL in Chemical Engineering

\begin{tabular}{|c|c|c|c|}
\hline S. No & Course Name & Project Examples & Project Outcomes \\
\hline 1 & $\begin{array}{l}\text { Chemical Engineering } \\
\text { Thermodynamics }\end{array}$ & $\begin{array}{l}\text { Heat effects, } \\
\text { Refrigeration, Steam } \\
\text { Effects }\end{array}$ & $\begin{array}{l}\text { 1) Application of first and second law of thermodynamics to a defined process or equipment. } \\
\text { 2) Role of compressors, heat exchangers, valves etc. }\end{array}$ \\
\hline 2 & Transport Phenomena & $\begin{array}{l}\text { Energy, Mass, } \\
\text { Momentum Transfer }\end{array}$ & $\begin{array}{l}\text { 1) To be able to analyze various transport processes, develop a model. } \\
\text { 2) To provide a mathematical solution to the model developed }\end{array}$ \\
\hline 3 & $\begin{array}{l}\text { Process Design and } \\
\text { Simulation }\end{array}$ & $\begin{array}{l}\text { Reactor with mass } \\
\text { transfer, Counter- } \\
\text { Current Heat } \\
\text { Exchanger }\end{array}$ & $\begin{array}{l}\text { 1) To get introduced to the modelling and simulation of steady-state and dynamic behaviour. } \\
\text { 2) Develop the mathematical models and solutions by applying various numerical methods to the } \\
\text { basic Chemical engineering problems in mass, heat and momentum transfer. }\end{array}$ \\
\hline 4 & $\begin{array}{l}\text { Chemical Process } \\
\text { Calculations }\end{array}$ & $\begin{array}{l}\text { Liquefaction, } \\
\text { Humidity, } \\
\text { Crystallization }\end{array}$ & $\begin{array}{l}\text { 1) To apply the principles of process calculations in the project, design and complex systems. } \\
\text { 2) To learn modern estimation techniques of process calculations to solve chemical engineering } \\
\text { problems. }\end{array}$ \\
\hline 5 & $\begin{array}{l}\text { Computational Fluid } \\
\text { Dynamics }\end{array}$ & $\begin{array}{l}\text { Heat Conduction in } \\
2 \mathrm{D} \text { and } 3 \mathrm{D} \text {, Fluid } \\
\text { Properties }\end{array}$ & $\begin{array}{l}\text { 1) To understand designing principles } \\
\text { 2) To know how the parameters affect the design. } \\
\text { 3) Design of Igloo, Flow-through a slab or pipes. }\end{array}$ \\
\hline
\end{tabular}

\section{Results \& Discussions}

The SPBL model enhances technological abilities of the students and also provides a look at major studies that show a positive impact of SPBL on academic achievement, student's mastery of modern competencies like critical thinking and problem-solving and also address the diversified needs of learners. It closes achievement gaps and increases motivation to learn.

On the part of students, they were puzzled and looked frustrated initially because they weren't familiar with work on a problem as groups in school but with the time they looked settled and motivated. At the end of the activity when students were asked to discuss SPBL methodology the bulk agreed that it promoted a better understanding of the matter, improved communication skills during discussions with team members and the facilitator and exposed new ideas during a short period of time. During class presentations, following strengths and weaknesses of students were revealed:-

1. All the groups concluded that the choice of a heat pump/air conditioner was the most preferred option.

2. Only one group performed the calculations accurately by taking non-ideal gas behaviour into account at high pressures. Some groups also made mistakes in unit conversions.

3. Regarding safety and environmental issues most of the groups touched these topics generally with no reference to the main problem. These topics were added to instil in students to discover new engineering horizons at their own.

\section{Merits of Sustainable Project-Based Learning}

1. Collaboration: Relationships shaped in collaboration are a massive part of SPBL. Students learn the ways to work better through groups provide input, listen to others, and also resolve conflicts when they happen and also build a positive relationship with teachers. This reinforces the greatness of learning. Students form a relationship with community members while working on projects, and gain insight for careers.

2. Problem Solving: Students need learning the art to solve important problems, like the real issues of community, effectively learning from failures and starting over again. (Johnson, 1999)

3. Creativity: Students also must apply creative skills to think, to innovate the new product designs, and explore the possibilities for projects.

4. In-Depth Understanding: Students develop their research skills and increase the learning of applied content away from facts and memorization.

5. Self-Confidence: Students get a voice and also learn to take their work proudly, and boost their purpose.

6. Critical Thinking: Here the Students learn to see the problems critically, ask questions and come up with solutions for the project.

7. Perseverance: Working on the projects, students learn the art of managing obstacles effectively, learn from failures and start from scratch.

8. Project Management: Students need learning the art of managing projects and assignments efficiently.

9. Curiosity: Students explore the curiosities, and ask questions and also develop the love for learning.

10. Empowerment: Students take project ownership, reflect on progress and celebrate their accomplishments.

\section{Conclusions}


Several conclusions are drawn from this study as follows:1. Traditional teacher-centred methodology can't be eliminated at the associate-level degrees unless students are taught SPBL at secondary schools or have sufficient experience of SPBL in pre-requisite courses.

2. Problem crafting should be done carefully. During this activity, the teacher should also consult his colleagues and review his problem with them. Actually, a committee should be formed to research and approve problems before those are presented to students (Woods et al., 2000).

3. Formation of groups to market collaborative learning should be done at the beginning of the course and before the implementation of SPBL. This will able to help resolve issues among group members and improve their understanding of one another before they embark upon SPBL. This can ensure productive learning where each member of the group would be involved.

4. The teacher's attitude to conduct SPBL is extremely important to stay students motivated and focused on their problem.

\section{Acknowledgement}

We would like to express our special thanks of gratitude to faculty who provided us with the golden opportunity to perform this wonderful project, which also helped us in doing a lot of research and we got to learn so many new things. Our special thanks to Miss Sarika Madam who helped us in preparing the survey form.

We would also like to thank our parents and friends who helped us a lot in finalizing this project within the limited timeframe.

\section{References}

1. De Los Rios, I., Cazorla, A., Díaz-Puente, J. M., \& Yagüe, J. L. (2010). Project-based learning in engineering higher education: two decades of teaching competences in real environments. Procedia-Social and Behavioral Sciences, 2(2), 1368-1378.

2. Shinde, V. (2014). Design of course level projectbased learning models for an Indian Engineering Institute: An assessment of students 'learning experiences and learning outcomes. Institut for Planlægning, Aalborg Universitet.

3. Wang, J., Song, Z., \& Li, Q. (2016). Reform of an Experimental Course of Chemical Engineering Based on Project-Based Teaching Method. Open Access Library Journal, 3(8), 1- 4.

4. Shekar, A. (2007). Active learning and reflection in product development engineering education. European Journal of Engineering Education, 32(2), 125-133.

5. Seidel, R., Shahbazpour, M., Walker, D., Shekar, A., \& Chambers, C. (2011). An innovative approach to developing students' industrial problem-solving skills. In 7th International CDIO Conference.
6. Duch, B. J., Groh, S. E., \& Allen, D. E. (2001). The power of problem-based learning: a practical" how to" for teaching undergraduate courses in any discipline. Stylus Publishing, LLC.

7. Jollands, M., Hadgraft, R. G., Ward, L., \& Grundy, I. (2005). Student engagement in project-based courses in first-year chemical engineering at RMIT University. In 4th ASEE/AaeE Global Colloquium on Engineering Education (p. 1055). Australasian Association of Engineering Education.

8. Thomas, J. (2000). A review of research on project-based learning. Report prepared for The Autodesk Foundation 2000. http://www. AutoDesk. com/foundation.

9. Prince, M. J., \& Felder, R. M. (2006). Inductive teaching and learning methods: Definitions, comparisons, and research bases. Journal of engineering education, 95(2), 123-138.

10. Polanco, R., Calderon, P., Delgado, F., Little, P., \& Kandlbinder, P. (2001). Problem-based learning in engineering students: Its effects on academic and attitudinal outcomes. The Power of Problembased Learning. P. Little and P. Kandlbinder Eds, 111-125.

11. Banerjee, S. (2015). A group project-based approach to induce learning in engineering thermodynamics. age, 26, 1 .

12. Tatar, E., \& Oktay, M. (2011). The effectiveness of problem-based learning on teaching the first law of thermodynamics. Research in Science \& Technological Education, 29(3), 315-332.

13. Bloom, B. (1956). Taxonomy of educational objectives. Handbook I: Cognitive Domain, Longman, New York.

14. Smith, J. M., Van Ness, H. C., and Abbott. M.M. (2005). Introduction to Chemical Engineering Thermodynamics .7th ed, Mc Graw Hill.

15. Narayanan, K. V. (2009). Chemical Engineering Thermodynamics. Prentice-Hall of India Pvt Ltd.

16. Krishnan, S., \& Nalim, M. R. (2009). Projectbased learning in introductory thermodynamics. $116^{\text {th }}$ ASEE Annual Conference.

17. Johnson, P. A. (1999). Problem-based, cooperative learning in the engineering classroom. Journal of professional issues in engineering education and practice, 125(1), 8-11.

18. Woods, D. R., Felder, R. M., Rugarcia, A., \& Stice, J. E. (2000). The future of engineering education III. Developing critical skills. change, 4, 48-52. 